\title{
Life cycle environmental impacts of disposable medical masks
}

\author{
Burçin Atılgan Türkmen ${ }^{1}$ (D)
}

Received: 29 June 2021 / Accepted: 4 November 2021 / Published online: 29 November 2021

(c) The Author(s), under exclusive licence to Springer-Verlag GmbH Germany, part of Springer Nature 2021

\begin{abstract}
A massive increase in the use and production of masks worldwide has been seen in the current COVID-19 pandemic, which has contributed to reducing the transmission of the virus globally. This paper aims to evaluate the life cycle environmental impacts of disposable medical masks to identify the life cycle stages that cause the highest impact on the environment. A further goal is to estimate the total environmental impacts at the global level in 2020 . The inventory data was constructed directly from the industry. The system boundary of the study is from cradle to grave comprising raw material extraction and processing, production, packaging, distribution, use, and disposal as well as transport and waste management along the supply chain. Eleven environmental impacts have been estimated. The results suggest that the global warming potential of a disposable medical mask is $0.02 \mathrm{~g} \mathrm{CO}_{2}$-eq. for which the main contributor is the raw material supply $(40.5 \%)$ followed by the packaging $(30.0 \%)$ and production (15.5\%). Sensitivity analysis was carried out to test the environmental impacts. In total, 52 billion disposable medical masks used worldwide consumes 22 $\mathrm{TJ}$ of energy in 2020. The global warming potential of disposable medical masks supplied in a year of the COVID-19 pandemic is $1.1 \mathrm{Mt} \mathrm{CO}_{2}$ eq. This paper assessed the hotspots in the medical mask. The findings of this study will be of interest to policymakers, global mask manufacturers, and users, allowing them to make more informed decisions about the medical mask industry.
\end{abstract}

Keywords COVID-19 $\cdot$ Disposable masks $\cdot$ Cleaner production $\cdot$ Environmental sustainability $\cdot$ Life cycle assessment

$\begin{array}{ll}\text { Abbreviations } \\ \text { ADP } & \text { Abiotic depletion potential of elements } \\ \text { ADP } & \text { Fossil abiotic depletion potential of fossil fuels } \\ \text { AP } & \text { Acidification potential } \\ \text { CML } & \text { Centrum Voor Milieuwetenschappen } \\ \text { DCB } & \text { Dichlorobenzene } \\ \text { EP } & \text { Eutrophication potential } \\ \text { FAETP } & \text { Freshwater aquatic ecotoxicity potential } \\ \text { GWP } & \text { Global warming potential } \\ \text { HTP } & \text { Human toxicity potential } \\ \text { ISO } & \text { International Standardization Organization } \\ \text { LCA } & \text { Life cycle assessment } \\ \text { MAETP } & \text { Marine aquatic ecotoxicity potential } \\ \text { ODP } & \text { Ozone layer depletion potential } \\ \text { POCP } & \text { Photochemical ozone creation potential }\end{array}$

Responsible Editor: Lotfi Aleya

Burçin Atılgan Türkmen

burcin.atilganturkmen@bilecik.edu.tr

1 Department of Chemical Engineering, Bilecik Şeyh Edebali University, Bilecik 11230, Turkey
PP Polypropylene

TETP Terrestrial ecotoxicity potential

WHO World Health Organization

\section{Introduction}

In Wuhan, China, the World Health Organization (WHO) China was informed of cases of unknown aetiology of pneumonia detected at the end of December 2019. The WHO first announced on 12 February 2020 that the cause of these symptoms was a new form of coronavirus (2019nCoV), and on 11 February 2020, the epidemic was named the "COVID-19" pandemic (WHO 2020c). The disease quickly acquired an international dimension and infected the entire world (WHO 2020e; Zheng 2020). COVID-19 is mainly a respiratory disease. The WHO confirmed personto-person transmission of COVID-19 through respiratory droplets. Respiratory droplets move through the air as you breathe, sneeze, or speak. These droplets can then fall in the mouths or noses of those near you or be breathed in (WHO 2020a). 
Different proposals have been put forward by governments at all levels to avoid the spread of the virus, including lockdown, social distancing, restriction of movement, isolation, avoiding public, or crowded spaces, as well as the use of personal protective equipment such as face masks (Fadare \& Okoffo 2020). The WHO suggests wearing a face mask in public, where social distance interventions are difficult to sustain, and in places of substantial community-based dissemination (WHO 2020a, b). Face masks protect the nose and help to block exhaled droplets and particulate matter to avoid further spread of COVID-19, which is caused by the SARS-CoV-2 virus (Liu and Zhang 2020; WHO 2020b). Mask usage has established a new normal in many countries as a result of its effectiveness in containing communicable diseases during the COVID-19 pandemic.

A face mask serves as a physical shield in front of the nose and mouth (WHO 2020a). When worn correctly, this type of mask prevents the sick person's respiratory droplets from spreading to the mouth and nose (Leung et al. 2020). Several different kinds of face masks provide users with various degrees of protection. Masks may be disposable or reusable. Industrial half-or full-face respirators with attached cartridge filters and handmade or consumer fabric masks are reusable; disposable ones include N95 respirators and surgical masks. The filtering capability depends on the materials used and the design of the engineering equipment, and therefore the level of protection (Chua et al. 2020).

A recent study has shown that medical masks can prevent symptomatic individuals from transmitting common cold coronaviruses and influenza viruses in actual conditions (Greenhalgh et al. 2020). The disposable medical mask is 3 times more effective than a cloth mask at preventing transmission (Howard et al. 2020). The disposable medical mask will also not provide maximum protection if it does not fit the face correctly. In the case of contamination, moisture, or wear, masks should be changed for new ones (WHO 2020a).

Since the early 1900s, masks have been used by healthcare workers to avoid surgical wound infection (Oberg and Brosseau 2008). In Asian countries, masks are widely used by the public. Since the 2003 SARS outbreak, face mask use has become increasingly widespread. During the SARS outbreak, $76 \%$ of the population in Hong Kong used a face mask (ECDC 2020).

A growing number of countries make it obligatory to wear face masks outside the home (WHO 2020a, d). The global consumption of face masks has seen a sixfold rise since the beginning of the COVID-19 pandemic (WHO 2020d). China's daily production of medical masks had climbed to 14.8 million by February 2020. In Japan, almost 600 million face masks were required by April 2020 (Selvaranjan et al. 2021).

The increased use of face masks has drawn attention to the amount of plastic waste and the other environmental issues that will be generated by the use of face masks. The increased use of masks results in a significant increase in mask production, as well as higher consumption of energy and raw materials (Selvaranjan et al. 2021). If every individual in the UK wore a new single-use surgical face mask every day for a year, the UK would generate around 128,000 $t$ of non-recyclable plastic waste (Allison et al. 2020). For that reason, a new environmental problem has been created by the rise in the manufacture and the use of face masks worldwide.

Globally, disposable medical masks are used millions of times a day, and yet and environmental impacts of this product are scarcely known. There are a limited number of studies that assess the environmental sustainability of face masks (Akarsu et al. 2021; Allison et al. 2020; Davies et al. 2013; Fadare and Okoffo 2020; Klemeš et al. 2020; Lee et al. 2021; Schmutz et al. 2020; van Straten et al. 2021). Some of the papers compared the environmental impacts of the selected type of masks such as reusable masks and disposable medical masks (Davies et al. 2013; Lee et al. 2021; Schmutz et al. 2020; van Straten et al. 2021). The scope and selected mask type vary across the papers. Most of the papers only focus on the solid waste problem of the masks (Akarsu et al. 2021; Allison et al. 2020; Fadare and Okoffo 2020). Although the information was available regarding the waste problem at the end of their life cycle, very little information was supplied concerning the life cycle environmental impacts of medical masks.

This study aims to assess the life cycle environmental impact of the disposable medical face masks and identify hotspot activities and key substances for improvement. This LCA study has been performed using real and detailed data obtained from a producer in Turkey. The entire value chain from extraction of raw materials to the end of life is considered. For 2020, total life cycle environmental impacts resulting from the total manufacturing of disposable medical face masks have been estimated in the global dimension.

The methods, assumptions, and inventory data used in the study are detailed in the following parts.

\section{Methodology}

In this paper, life cycle assessment (LCA) has been used as a tool to quantify the environmental impacts of disposable medical face masks. LCA is the most common tool for quantifying the environmental effects associated with a product, process, or service's entire life (Baumann and Tillman 2004). LCA was performed in accordance with the international standards of the ISO 14040 and ISO 14044 series (ISO 2006a, b). These standard series describe the LCA's four steps: goal and scope definition, 
inventory analysis, impact assessment, and interpretation. The purpose of the study, the functional unit, the boundary conditions, and the assumptions for the context in which evaluation is being made are defined in the goal and scope definition stage. The second step of the LCA is inventory analysis. The inventory analysis specifies the processes required for raw materials production, use of auxiliary materials, water, and energy during manufacturing, emissions to air, water, and soil during manufacturing, transport of raw materials, and packaging materials. The LCA modelling was carried out in GaBi v10.5 software package (Sphera 2021). Based on inventory data and system boundaries, this software calculates the environmental impact potentials of a product, service, or manufacturing system resulting from material inputs and outputs such as energy use or air emissions. Characterisation methods for environmental impact categories such as global warming potential, acidification potential, and abiotic depletion potential are included in GaBi (Sphera 2021). The impact assessment step evaluates the potential impacts on the environment using the inventory data. The life cycle environmental impacts have been quantified using the CML 2001 impact assessment method (Guinée et al. 2002). Finally, the interpretation step sets out the conclusions and recommendations for the study.

The methodology, goal and scope of this research, inventory data and assumptions, and results are detailed in the following parts.

\section{Aims and scope}

The goal of this paper is to estimate the life cycle environmental impacts of the disposable medical face mask and to identify the life cycle stages that cause the highest impact on the environment. A further goal is to estimate the total environmental impacts at the global level in 2020.

The functional unit is considered as "a 3-layer single-use medical face mask with nose wire". Authorities recommend these types of face masks, and they are widely used around the world. In total, 52 billion face masks were manufactured in 2020 globally (OceansAsia 2020).

The system boundaries included all activities from cradle to grave including raw material extraction and processing, manufacturing, packaging, distribution, use, and disposal as well as transport and waste management along the supply chain. The life cycle of disposable medical face masks along the supply chain is outlined in Fig. 1.

The disposable medical face mask manufacturing stage consists of body making and ultrasonic vending steps. The waste generated during the production is included in the system boundary. For the face mask production stage, the manufacturing of the equipment used in the facility and construction and decommissioning of the buildings are not included due to a lack of specific data.

\section{Inventory analysis}

Primary data were collected from a face mask manufacturer in Turkey and data gaps were filled using inventories from the Ecoinvent database (Ecoinvent 2021). Detailed and real manufacturing data was used for life cycle modelling.

Medical face masks are classified in the European Standard EN 14,683 into two types (type I and type II) based on bacterial filtration efficiency, with type II further subdivided depending on whether the mask is splash resistant. Splash resistance is denoted by the letter "R" (CEN 2019). The specifications of the medical masks are presented in Table 1.

The focus of this research is on disposable medical face masks, type I. These types of masks are described as masks that are flat and attached to the head with straps that go around the ears. Type I medical masks are used to reduce the risk of infection spread, especially during epidemics or pandemics. The selected types of masks are manufactured using plastic variants such as polypropylene to protect against various types of infections. They do not contain latex or PVC material. They are manufactured using three layers of protection (CEN 2019).

The details of the inventory data for the raw materials used have been presented in Table 2. Primary data were collected on raw materials directly from the manufacturer in Turkey. The raw materials are extracted and processed then transported. The background data of the non-woven fabrics, plastic-coated aluminium, and polyurethane flexible foam were obtained from the Ecoinvent v3.7.1 (Ecoinvent 2021) but has been adapted as far as possible to Turkey's conditions by using the country-specific energy and transportation data.

The structure of a disposable medical face mask is divided into three parts. That is the 3 layers of non-woven fabric part, nose strip, and ear loops. The selected type of disposable medical face mask is produced from polypropylene (PP) spun bond and melt-blown non-woven fabrics, $20-25 \mathrm{~g} / \mathrm{m}^{2}$ in density. PP is one of the most widely manufactured plastics in the world and can easily be supplied as an oil-based polymer. Spun bond fabrics are produced in one continuous process from extruded filament fibre. Melt-blown fabric is produced by using high-speed hot air to extrude a polymer melt through a series of fine holes, resulting in fine, self-bonded fibres. The melt-blown fabric has a smaller pore size than spun-bond fabric, allowing for improved filtration effectiveness. Due to the lack of data, the same energy consumption was assumed for the production of spun bond and melt-blown non-woven fabrics based on literature (Faist Emmenegger et al. 2018). 
Fig. 1 Life cycle stages of disposable medical face mask
Table 1 Performance standards for medical face masks (CEN 2019)

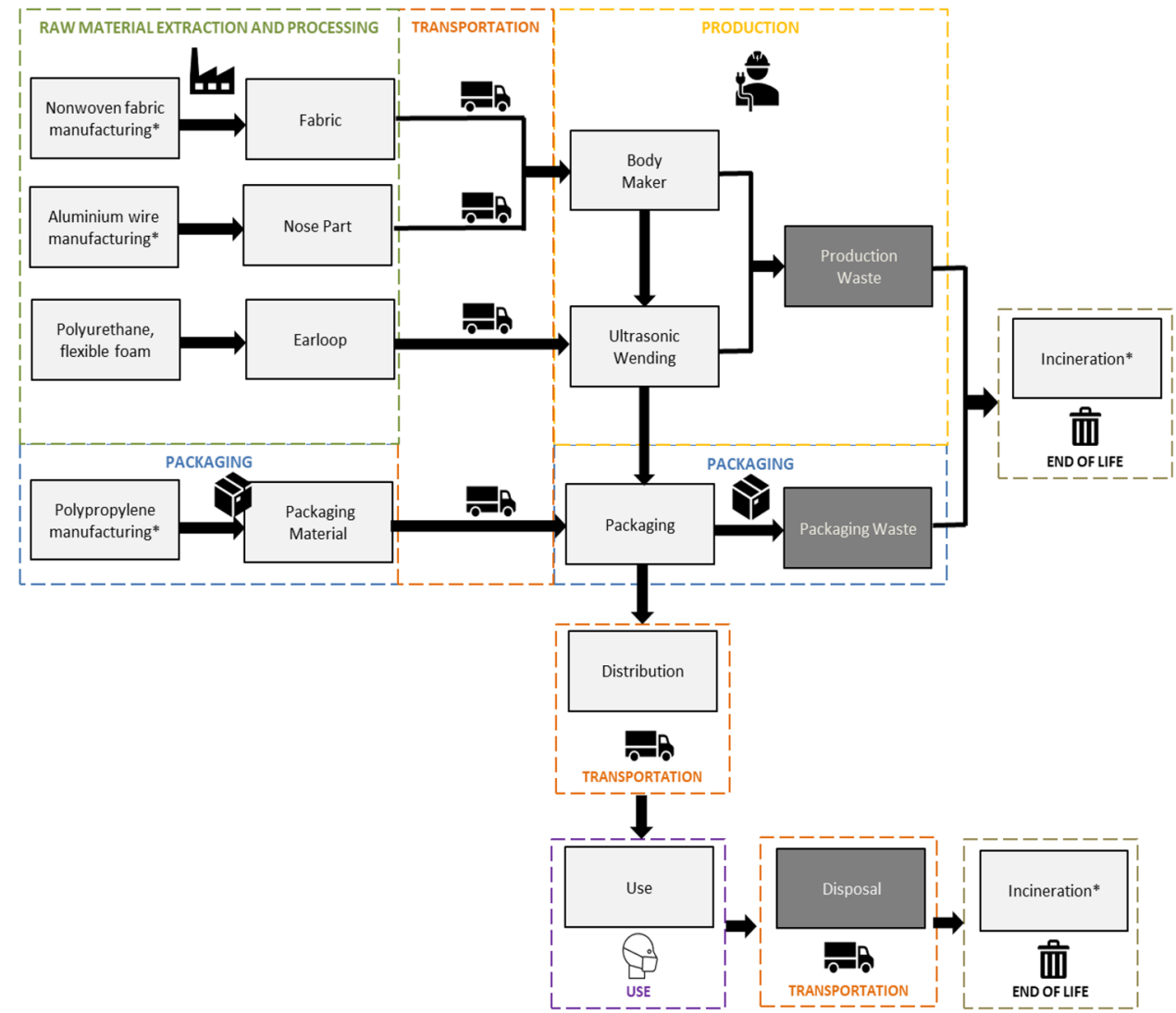

\begin{tabular}{llll}
\hline Test & Type I & Type II & Type IIR \\
\hline Bacterial filtration efficiency $(\mathrm{BFE}),(\%)$ & $\geq 95$ & $\geq 98$ & $\geq 98$ \\
Differential pressure $\left(\mathrm{Pa} / \mathrm{cm}^{2}\right)$ & $<40$ & $<40$ & $<60$ \\
Splash resistance pressure $(\mathrm{kPa})$ & Not required & Not required & $\geq 16,0$ \\
Microbial cleanliness $(\mathrm{cfu} / \mathrm{g})$ & $\leq 30$ & $\leq 30$ & $\leq 30$ \\
\hline
\end{tabular}

Table 2 Inventory data on raw materials and packaging materials

\begin{tabular}{lll}
\hline Raw material & $\begin{array}{l}\text { Amount }(\mathrm{g} / \\
\text { mask) }\end{array}$ & Source \\
\hline Fabric: spun bond polypropylene & 1.50 & Manufacturer \\
Fabric: melt-blown polypropylene & 0.80 & Manufacurer \\
Nose wire: plastic-coated aluminium & 0.38 & Manufacturer \\
Aluminium & 0.10 & Manufacturer \\
Plastic & 0.26 & Manufacturer \\
Earloop: polyurethane flexible foam & 0.32 & Manufacturer \\
Packaging: oriented polypropylene & 1.79 & Manufacturer \\
\hline
\end{tabular}

The nose wire is used to create the nose frame in the face mask, which keeps the medical face mask tightly attached to the nose. The nose strip is made of $0.5 \mathrm{~mm}$ diameter aluminium that has been white plastic-coated. The earloop used in each mask is produced from spandex. As given in
Table 2, flexible polyurethane foam is used as a raw material for the production of earloops.

As shown in Table 3, the transportation stage covers all relevant raw materials and packaging materials transport from producers to the facility, transportation of the masks from facility to customer, and transportation of the waste from facility or customer to the incineration. All transport is assumed to be by road using a lorry of Euro IV emissions class. The production facility for the masks is located at Bilecik. Transport distances from raw material sites to production facilities are obtained from the manufacturer. The data comprises the extraction and production of site locations, transportation distances, and types of transport used. Medical face mask materials are produced in Turkey. Nonwoven fabrics are manufactured in Gaziantep, materials for nose strips and packaging are manufactured in Istanbul, and earloop materials are manufactured in Bursa. 
The manufactured mask is transported to Europe. Turkey is one of the leading producers of nonwoven textile products (EDANA 2021) and one of the suppliers of face masks to Europe. In 2020, disposable medical mask exports to Turkey increased by approximately 123 times over the previous year, totalling nearly US\$217 million. Turkey exported the most disposable medical masks to Germany, with US $\$ 31.4$ million worth of products. Germany was followed by France with US\$25 million (TUIK 2020).

Medical face masks are manufactured in specialised facilities, on a machine line that assembles nonwoven fabric, ultrasonic welds of three layers of non-woven fabric, and stamps mask body with plastic-coated nose wire and elastic ear loops. Ultrasonic welding is then used to join different layers of nonwoven fabric. Electricity is consumed during the production of the mask. The energy consumption of each production step is presented in Table 4.

Data for electricity grid mix specific for Turkey were used based on the latest version of Ecoinvent v3.7.1 (Ecoinvent 2021). This dataset describes the electricity in Turkey for the year 2008. In this year, the share of natural gas, lignite, hard coal, and hydropower in the electricity mix was $49 \%, 21 \%, 7 \%$, and $17 \%$, respectively. Further electricity is generated from other renewables such as wind, geothermal, and solar power (Itten et al. 2014).

Medical face masks are supplied in sterile packs. Each of the masks is packed with transparent oriented polypropylene (OPP) packaging bag for disposable face mask individual packaging. The packaging stage includes the packaging raw material and energy consumption for the packaging of a mask. Details on the packaging data have been given in Tables 2, 3, and 4 .

Table 5 compiles the type and amount of waste and waste management methods. The waste management stage includes incineration of the solid waste generated from production, packaging, and disposal mask and package. The waste is collected and transported to the waste disposal site. It is assumed that all the wastes are treated as municipal waste and incinerated with energy recovery. The background data for municipal solid waste incineration is obtained from the database (Doka 2013).

\section{Results}

This part presents and analyses the environmental impacts of disposable medical face mask first for the selected functional unit related to the life cycle of a mask and then for the global use of this type of face mask in 2020. The results are shown in Table 6 showing the environmental impacts of the life cycle per mask. The contribution of different life cycle steps to the total impacts can be seen in Fig. 2. The comparison of the results with the literature is presented in the subsequent section followed by the total environmental impact results of the global use of disposable medical face masks in 2020 (Table 7). This is following the sensitivity analysis (Fig. 3) that considered the local use of masks and different packaging options.

The LCA software GaBi v.10.5 (Sphera 2021) was used to complete the study. The main modelled process based on $\mathrm{GaBi}$ software is presented in the Appendix. Eleven environmental impact categories assessed in this paper include global warming, resource depletion, eutrophication, acidification, ozone layer depletion, ecotoxicity, and human toxicity based on CML 2001-January 2016 (CML 2017).

\section{Environmental impacts per disposable medical mask}

The life cycle environmental impacts of a disposable medical mask are presented in Table 6, with the contributions

Table 4 Inventory data on medical face mask production electricity consumption

\begin{tabular}{lll}
\hline Production stage & Energy $(\mathrm{Wh} / \mathrm{mask})$ & Source \\
\hline Body making & 3.1 & Manufacturer \\
Ultrasonic welding & 0.3 & Manufacturer \\
Packaging & 0.6 & Manufacturer \\
\hline
\end{tabular}

Table 3 Inventory data on transportation

\begin{tabular}{llll}
\hline Raw material & Distance & Lorry size class & Source \\
\hline Spun bond polypropylene fabric & $1000 \mathrm{~km}$ & $16-32$ metric tons & Manufacturer/Ecoinvent \\
Melt-blown polypropylene fabric & $1000 \mathrm{~km}$ & $16-32$ metric tons & Manufacturer/Ecoinvent \\
Nose wire & $250 \mathrm{~km}$ & $16-32$ metric tons & Manufacturer/Ecoinvent \\
Earloop & $150 \mathrm{~km}$ & $16-32$ metric tons & Manufacturer/Ecoinvent \\
Packaging material & $300 \mathrm{~km}$ & $16-32$ metric tons & Manufacturer/Ecoinvent \\
Mask & $2800 \mathrm{~km}$ & $>32$ metric tons & Manufacturer/Ecoinvent \\
Production and packaging waste & $50 \mathrm{~km}$ & $16-32$ metric tons & Manufacturer/Ecoinvent \\
Mask waste & $50 \mathrm{~km}$ & $16-32$ metric tons & Manufacturer/Ecoinvent \\
\hline
\end{tabular}


Table 5 Inventory data on waste management

\begin{tabular}{llll}
\hline Waste type & $\begin{array}{l}\text { Amount }(\mathrm{g} / \\
\text { mask })\end{array}$ & Waste management technique & Source \\
\hline Production waste & 0.13 & Municipal solid waste incineration & Manufacturer \\
Spun bond polypropylene & 0.06 & Municipal solid waste incineration & Manufacturer \\
Melt-blown polypropylene & 0.03 & Municipal solid waste incineration & Manufacturer \\
Nose wire & 0.02 & Municipal solid waste incineration & Manufacturer \\
Earloop & 0.02 & Municipal solid waste incineration & Manufacturer \\
Packaging waste & 0.13 & Municipal solid waste incineration & Manufacturer \\
Oriented polypropylene & 0.13 & Municipal solid waste incineration & Manufacturer \\
Disposal mask & 2.82 & Municipal solid waste incineration & Manufacturer \\
Disposal package & 2.67 & Municipal solid waste incineration & Manufacturer \\
\hline
\end{tabular}

by considered life cycle stages provided in Fig. 2 . The results reveal that the life cycle of raw material supply is the main hotspot for abiotic depletion potential ADP, ADP fossil, acidification potential (AP), global warming potential (GWP), ozone layer depletion potential (ODP), photochemical oxidant creation potential (POCP), and terrestrial ecotoxicity potential (TETP). Waste incineration is the major contributor to freshwater aquatic ecotoxicity potential (FAETP), marine aquatic ecotoxicity potential (MAETP), and human toxicity potential (HTP). Most of the eutrophication potential (EP) occurs due to the production of the masks. Transportation is only a significant contributor ODP. Further discussion of the environmental impacts from the life cycle of disposable medical masks follows.

\section{Abiotic depletion potential}

As presented in Table 6, a disposable medical face mask depletes $35 \mathrm{~g} \mathrm{Sb}$-eq. of abiotic elements. The life cycle of raw materials contributes $76.3 \%$ to the total (see Fig. 2). The big contributors to this impact are the use of tellurium
(40.0\%), sodium chloride (29.3\%), gold (9.7\%), and copper $(7.3 \%)$.

\section{Abiotic depletion potential (fossil)}

Fossil resource depletion at the considered type of face mask's life cycle is estimated at $0.4 \mathrm{MJ}$ per mask (Table 6). The life cycle of raw materials $(50.0 \%)$, packaging of the mask $(37.2 \%)$, and the production of the medical face mask (10.7\%) are the major contributors to ADP fossil due to the manufacturing of PP.

\section{Acidification potential}

The disposable medical mask has an $\mathrm{AP}$ of $0.08 \mathrm{~g} \mathrm{SO}_{2}$-eq. per disposable medical mask. The emissions of $\mathrm{SO}_{2}$, NOx, and $\mathrm{N}_{2} \mathrm{O}$ to air contribute $66.4 \%, 14.8 \%$, and $6.9 \%$ of the total, respectively. As can be seen from Fig. 2, raw material extraction and processing (38.3\%), packaging of the product (\%38.3), and production (22.2\%) are the biggest contributors to the total AP.

Table 6 Life cycle environmental impacts of a mask

\begin{tabular}{|c|c|c|c|c|c|c|c|}
\hline Environmental impact category & Total & Raw material & Production & Packaging & Transportation & Use & End of life \\
\hline ADP (kg Sb eq.) & $3.5 \mathrm{E}-08$ & 2.7E-08 & 4.8E-09 & $6.5 \mathrm{E}-10$ & 3.8E-09 & - & $-9.2 \mathrm{E}-10$ \\
\hline ADP fossil (MJ) & 4.2E-01 & $2.1 \mathrm{E}-01$ & 4.4E-02 & $1.6 \mathrm{E}-01$ & $2.2 \mathrm{E}-02$ & - & $-1.2 \mathrm{E}-02$ \\
\hline $\mathrm{AP}\left(\mathrm{kg} \mathrm{SO}_{2}\right.$ eq.) & 7.9E-05 & $3.0 \mathrm{E}-05$ & $1.8 \mathrm{E}-05$ & $3.0 \mathrm{E}-05$ & $5.4 \mathrm{E}-06$ & - & $-4.4 \mathrm{E}-06$ \\
\hline EP (kg Phosphate eq.) & $2.2 \mathrm{E}-05$ & 7.4E-06 & $1.1 \mathrm{E}-05$ & $3.3 \mathrm{E}-06$ & $1.6 \mathrm{E}-06$ & - & $-1.2 \mathrm{E}-06$ \\
\hline FAETP (kg DCB eq.) & $2.0 \mathrm{E}-01$ & $1.9 \mathrm{E}-03$ & $2.0 \mathrm{E}-03$ & $2.2 \mathrm{E}-04$ & $2.0 \mathrm{E}-04$ & - & $2.0 \mathrm{E}-01$ \\
\hline GWP (kg CO 2 eq.) & $2.1 \mathrm{E}-02$ & 8.3E-03 & $3.2 \mathrm{E}-03$ & $6.1 \mathrm{E}-03$ & $1.4 \mathrm{E}-03$ & - & $1.5 \mathrm{E}-03$ \\
\hline HTP (kg DCB eq.) & 3.7E-02 & 4.1E-03 & $1.6 \mathrm{E}-03$ & $2.2 \mathrm{E}-04$ & $7.0 \mathrm{E}-04$ & - & $3.1 \mathrm{E}-02$ \\
\hline MAETP (kg DCB eq.) & $1.2 \mathrm{E}+03$ & $7.8 \mathrm{E}+00$ & $5.7 \mathrm{E}+00$ & $1.0 \mathrm{E}+00$ & 4.4E-01 & - & $1.1 \mathrm{E}+03$ \\
\hline ODP (kg R11 eq.) & 7.4E-10 & $4.0 \mathrm{E}-10$ & $8.1 \mathrm{E}-11$ & $8.0 \mathrm{E}-12$ & $2.6 \mathrm{E}-10$ & - & $-7.6 \mathrm{E}-12$ \\
\hline POCP (kg Ethene eq.) & $8.1 \mathrm{E}-06$ & $3.9 \mathrm{E}-06$ & $9.3 \mathrm{E}-07$ & $2.9 \mathrm{E}-06$ & 5.7E-07 & - & $-2.1 \mathrm{E}-07$ \\
\hline TETP (kg DCB eq.) & 4.4E-05 & $2.8 \mathrm{E}-05$ & $9.2 \mathrm{E}-06$ & $1.2 \mathrm{E}-06$ & 4.7E-06 & - & 8.8E-07 \\
\hline
\end{tabular}


Fig. 2 Contribution of different life cycle stages to the total impact

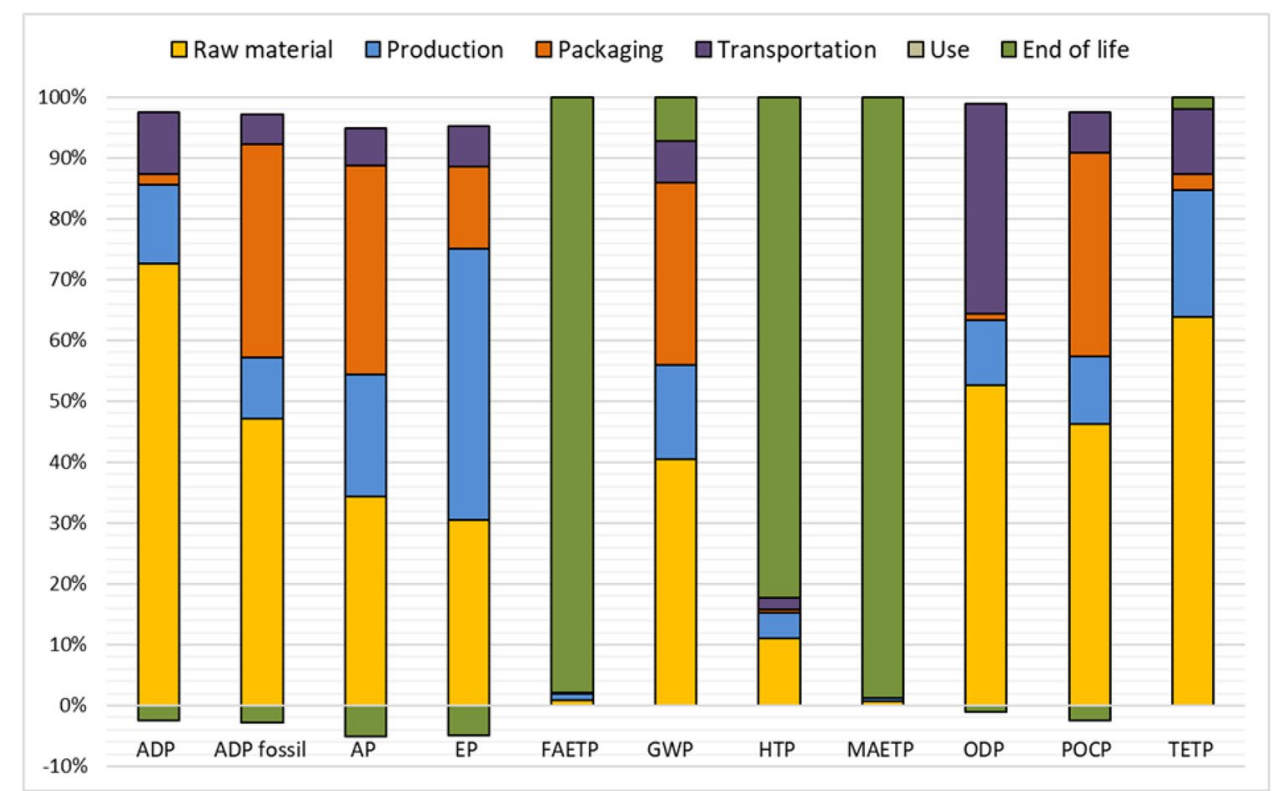

Table 7 Total annual life cycle environmental impacts of global mask usage

\begin{tabular}{ll}
\hline Environmental impact category & Value \\
\hline ADP (kg Sb eq.) & $1.8 \mathrm{E}+03$ \\
ADP fossil (MJ) & $2.2 \mathrm{E}+10$ \\
AP (kg SO ${ }_{2}$ eq.) & $4.1 \mathrm{E}+06$ \\
EP (kg Phosphate eq.) & $1.1 \mathrm{E}+06$ \\
FAETP (kg DCB eq.) & $1.1 \mathrm{E}+10$ \\
GWP (kg CO & eq.) \\
HTP (kg DCB eq.) & $1.1 \mathrm{E}+09$ \\
MAETP (kg DCB eq.) & $1.9 \mathrm{E}+09$ \\
ODP (kg R11 eq.) & $6.0 \mathrm{E}+13$ \\
POCP (kg Ethene eq.) & $3.9 \mathrm{E}+01$ \\
TETP (kg DCB eq.) & $4.2 \mathrm{E}+05$ \\
\hline
\end{tabular}

\section{Eutrophication potential}

Table 6 and Fig. 2 reveal that the EP for a disposable medical face mask is equal to $0.02 \mathrm{~g} \mathrm{PO}_{4}$-eq. with $49.2 \%, 33.8 \%$, and $14.9 \%$ arising from the production, raw material supply, and packaging step, respectively. The impact from the production is dominated by body-making step due to the high energy consumption. This impact is mainly due to the emissions of $\mathrm{NOx}$ and $\mathrm{PO}_{4}$ to air and water.

\section{Freshwater aquatic ecotoxicity potential}

As presented in Table 6, a disposable medical face mask has an estimated FAETP of $0.2 \mathrm{~kg}$ dichlorobenzene (DCB)eq. Almost all this impact is due to the emissions to the freshwater of metals including nickel, beryllium, cobalt, vanadium, and copper mostly during the incineration stage $(97.9 \%)$.

\section{Global warming potential}

As can be seen from Table 6, the estimated value for GWP for a mask is $21.5 \mathrm{~g} \mathrm{CO}_{2}$-eq. The $\mathrm{CO}_{2}$ emissions account for $89.5 \%$ of the total GWP, with contributions of $9.2 \%$ from $\mathrm{CH}_{4}$. The biggest contributors to the greenhouse gas emissions are the raw material supply $(40.5 \%)$, packaging of the mask $(30.0 \%)$, and the medical mask production $(15.5 \%)$ parts. The next largest contributor to GWP is transportation (7.4\%) (see Fig. 2). The raw materials' contribution is mainly due to fabric part manufacturing.

\section{Human toxicity potential}

The HTP from the disposable medical mask is estimated at 37 g DCB-eq. per mask (Table 6), due to beryllium (79.4\%) to freshwater. The major source of this impact is the incineration of the wastes, contributing $82.3 \%$ to the total. The second-largest contributor is the raw material extraction and processing stage (11.0\%) due to the high energy consumption of this stage (Fig. 2).

\section{Marine aquatic ecotoxicity potential}

As shown in Table 6 and Fig. 2, the MAETP of a disposable medical mask is equal to $1.2 \mathrm{t}$ DCB-eq. of which $98.7 \%$ is due to waste incineration. As with other ecotoxicity potentials, this impact is due to beryllium emissions (90\%) to freshwater from this stage. 
Fig. 3 Results for the sensitivity analysis

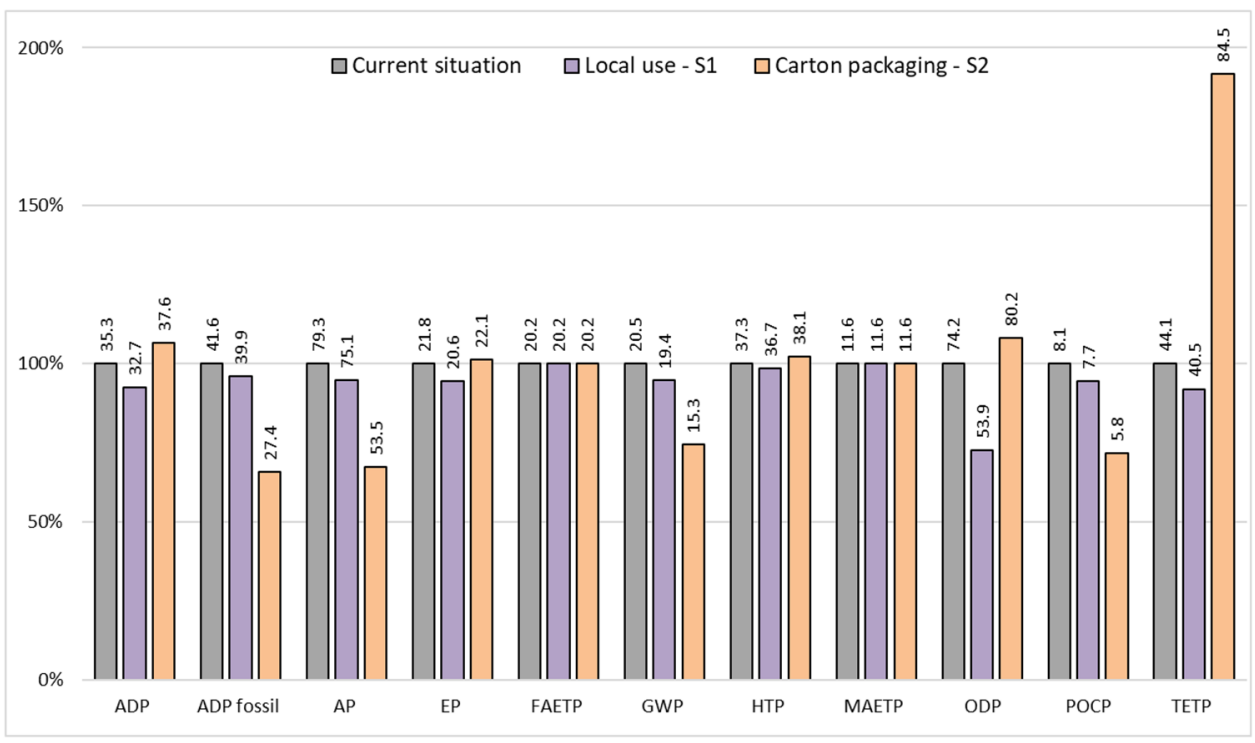

\section{Ozone layer depletion potential}

The ODP of the disposable medical face mask is estimated at $0.7 \mu \mathrm{g}$ R11-eq. per disposable medical facemask. This is mainly due to the life cycle of raw materials used for the mask production (53.7\%) (see Fig. 2). The other biggest contributors are transportation $(35.3 \%)$ and production (10.9\%) stages. Halons 1301 (54.3\%), carbon tetrachloride $\left(\mathrm{CCl}_{4}\right)(37.7 \%)$, and halon 1211 $(6.5 \%)$ releases are the main environmental burdens causing this impact.

\section{Photochemical oxidant creation potential}

The disposable medical face mask has a POCP of $8.1 \mathrm{mg}$ Ethene-eq. per mask. As shown in Fig. 2, it is mainly due to raw material supply which contributes $48.7 \%$ to the total. The raw material supply stage adds to the POCP via the life cycle of the fabric part. The other main burdens contributing to this impact include the packaging (35.3\%), production (11.5\%), and transportation $(7.0 \%)$ stages. The emissions of $\mathrm{SO}_{2}(25.7 \%)$, hydrocarbons (10.7\%), and $\mathrm{CH}_{4}(5.9 \%)$ are the main contributors to this impact.

\section{Terrestrial ecotoxicity potential}

The TETP of a face mask is estimated at $0.04 \mathrm{~g} \mathrm{DCB}$ eq. (Table 6), respectively. Chromium (55.7\%), mercury $(22.2 \%)$, and vanadium $(5.9 \%)$ emissions to air and soil are the main contributors. The life cycle of raw materials, production, and transportation contribute $63.9 \%, 20.9 \%$, and $10.6 \%$, respectively.

\section{Comparison of results with literature}

In this paper, CML 2001 updated January 2016 has been used for the calculation of the results. Due to the difference in the impact assessment methods used, the results of this work are compared only to the GWP estimated in other studies. The estimate by Lee et al. (2021) of $18.7 \mathrm{~g} \mathrm{CO}_{2}$ eq./mask is quite close to the present study's values of $21.5 \mathrm{~g} \mathrm{CO}_{2}$ eq./ mask. Another study by Allison et al. (2020) estimated GWP at $58.8 \mathrm{~kg} \mathrm{CO}_{2}$ eq. per mask which is more than double the value found in the previous study. It is mainly due to the transportation of materials to the UK by air freight from China. In this study, raw material transportation accounts for a significant portion (71.3\%) of GWP. Given the assumptions and countries of origin, the GWP findings of this study are comparable to those found in the literature.

\section{Total environmental impacts of global use of disposable medical masks in $\mathbf{2 0 2 0}$}

This part of the study presents the total environmental impacts of the global use of disposable medical face masks in 2020, based on the impacts calculated for a single mask produced in Turkey discussed in the previous section.

Table 7 demonstrates the annual environmental effects of masks used worldwide. In total, 52 billion disposable medical masks being produced in 2020 globally (OceansAsia 2020).

As indicated in Table 7, 52 billion disposable medical masks produced worldwide in 2020 consumed 22 TJ of energy. The total annual GWP is estimated at around $1.1 \mathrm{Mt}$ $\mathrm{CO}_{2}$ eq. from the global mask sector.

Textile manufacturing is one of the most polluting sectors, emitting 1.2 billion tonnes of $\mathrm{CO}_{2}$ eq. each year, more 
than international aircraft and maritime transportation (Ellen MacArthur Foundation 2017). Greenhouse gases emitted by disposable masks used last year amounted to approximately $1 / 1000$ th of the total annual greenhouse gases emitted by the global textile sector. These numbers demonstrate the magnitude of the environmental effects caused by the use of masks.

\section{Sensitivity analysis}

The sensitivity analysis investigates the impact of the selected parameters on the environmental sustainability of disposable medical face masks: transportation distance for the product and the type of packaging. The results of the sensitivity analysis are summarised and compared in Fig. 3 and discussed below.

\section{Sensitivity analysis of local use (S1)}

The findings of this study were obtained by modelling disposable medical mask production in Turkey using materials sourced from Turkey and the manufactured mask usage in Europe. The details related to transportation are presented in Table 3. The contribution of transportation of the raw materials and packaging materials ranges from 0.1 to $35.3 \%$ across the impact categories (see Fig. 2).

The manufactured masks are also used in Turkey. For sensitivity analysis, transportation distances for the product are decreased from 2800 to $100 \mathrm{~km}$ to assess the environmental impacts of the mask usage in Turkey. As presented in Fig. 3, the biggest reduction (27.4\%) as a result of using the masks in the country where they are manufactured is found for ODP. The results suggest that local use of the medical masks would cause a modest increase, $4-8 \%$ for seven environmental impact categories. The effect on the rest of the impacts is negligible. Therefore, most impacts are sensitive to the transportation distances for the product.

\section{Sensitivity analysis of carton packaging (S2)}

In this part of the study, the effect of using carton packaging instead of individual plastic bag packaging is assessed. The face mask is assumed to pack in a group of 10 in a paper box weighing approximately $0.08 \mathrm{~kg}$ per mask.

The results in Fig. 3 show that packaging masks in a carton instead of plastic result in GWP savings of about $25.4 \%$ or $5.2 \mathrm{~g} \mathrm{CO}_{2}$ eq. per mask; this is equivalent to around 270.4 kilotons of $\mathrm{CO}_{2}$ eq. based on the amount of global usage of the medical masks. Savings in other impacts range from 28.3 (POCP) to $34.1 \%$ (ADP fossil). These reductions are due to lower energy and material consumption for the manufacturing of paper boxes than plastic packaging. When compared to the current situation, FAETP and MAETP remain the same for this sensitivity model. The increase (up to 91.6\%) is found for the ADP, EP, HTP, ODP, and TETP (see Fig. 3).

\section{Conclusions}

This study estimated the life cycle environmental impacts of a disposable medical face mask. Furthermore, it considered the total global effects of using this type of face masks in 2020 . The system boundaries included all activities from cradle to grave. Local usage of the mask and different packaging types are considered in the sensitivity analysis to examine the effect of these parameters on the environmental impacts.

The results suggest that the greenhouse gas emissions of a disposable medical face mask are $0.02 \mathrm{~g} \mathrm{CO}_{2}$-eq. for which the main contributor is the raw material supply (40.5\%) followed by the packaging $(30.0 \%)$ and production $(15.5 \%)$. Given the assumptions and countries of origin, the GWP findings of this study are comparable to those found in the literature.

Raw material supply is the main hotspot for ADP, ADP fossil, AP, GWP, ODP, POCP, and TETP. Waste incineration is the major contributor to FAETP, MAETP, and HTP. Most of the EP occurs due to the production of the masks. Transportation is only a significant contributor to ODP. The sensitivity analysis indicated that the transportation of the manufactured masks and carton packaging influences the considered environmental impacts.

In total, 52 billion disposable medical masks used worldwide consumed $22 \mathrm{TJ}$ of energy in 2020. The global warming potential of disposable medical masks supplied in 2020 is $1.1 \mathrm{Mt} \mathrm{CO}_{2}$ eq. Globally, the textile industry emits 1.2 billion tonnes of $\mathrm{CO}_{2}$ eq. per year. The significance of the environmental effects caused by the use of masks is demonstrated in this comparison.

This study is expected to be useful for policymakers, global mask manufacturers, and users to identify hotspots and to find environmentally friendly solutions. Based on the findings, some actions for improving the environmental sustainability of medical masks throughout their entire life cycle can be proposed to reduce the life cycle environmental impact of the identified hotspots. The raw material supply stage's impact could be reduced by using alternative raw materials to make the fabric body, ear loops, and nose wire parts. Recycling these parts after use may also help to reduce the disposable medical mask's environmental impact over its entire life cycle. Other options would be reducing the amount of electricity used and the mask's weight. Furthermore, as discussed in the sensitivity analysis, using masks locally and swapping the carton packaging would reduce some of the environmental impact categories.

The current work can be extended to compare the environmental impacts of different face masks such as N95 respirators or reusable fabric masks. 


\section{Appendix}

Basic LCA model based on GaBi

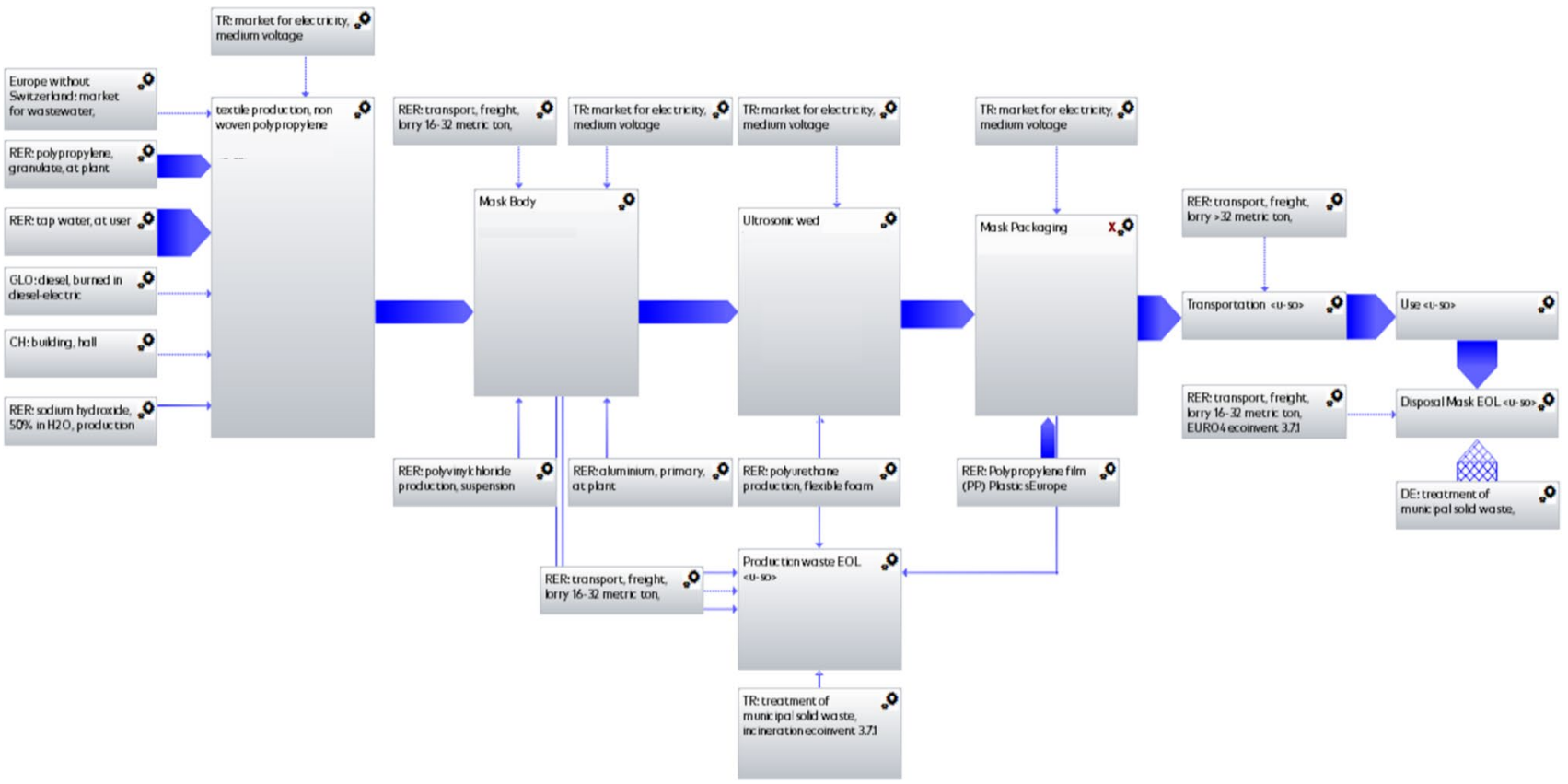

Author contribution Burçin Atılgan Türkmen confirms sole responsibility for the following: study conception and design, data collection and calculation, LCA analysis and interpretation of results, sensitivity analysis, and manuscript preparation.

Funding This work is supported by the Scientific Research Project Fund of Bilecik Seyh Edebali University under the project number 2020-02.BŞEÜ.03-06.

\section{Declarations}

Ethics approval and consent to participate Not applicable.

Consent for publication Not applicable.

Competing interests The authors declare no competing interests.

\section{References}

Akarsu C, Madenli Ö, Deveci EÜ (2021) Characterization of littered face masks in the southeastern part of Turkey. Environ Sci Pollut Res 28(34):47517-47527. https://doi.org/10.1007/ s11356-021-14099-8

Allison A, Ambrose-Dempster E, Domenech T, Bawn M, Arredondo M, Chau C, Chandler K, Dobrijevic D, Hailes, Lettieri P, Liu C, Medda F, Michie S, Miodownik M, Purkiss D, Ward J (2020) The environmental dangers of employing single-use face masks as part of a COVID-19 exit strategy. UCL Open: Environment Preprint. UCL Press: London https://doi.org/10.14324/111.444/000031.v1

Baumann H, Tillman A-M (2004) Introduction to LCA. In The Hitch Hiker's Guide to LCA : An Orientation in Life Cycle Assessment Methodology and Application (pp. 19-69). Studentlitteratur

CEN (2019) Medical face masks - Requirements and test methods. Medical face masks - Requirements and test methods - EN 14683:2019+AC. CEN - European Committee for Standardization, Brussels

Chua MH, Cheng W, Goh S, Kong J, Li B, Lim J, Mao L, Wang S, Xue K, Yang L, Ye E, Zhang K, Cheong W, Tan B, Li Z, Tan B, Loh XJ (2020) Face masks in the new COVID-19 normal: Materials, testing, and perspectives. Research 2020:1-40. https://doi.org/10. 34133/2020/7286735

CML (2017) CML-IA characterisation factors, January 2016 Update. http://cml.leiden.edu/software/data-cmlia.html

Davies A, Thompson K-A, Giri K, Kafatos G, Walker J, Bennett A (2013) Testing the efficacy of homemade masks: would they protect in an influenza pandemic? Disaster Med Public Health Prep 7(4):413-418

Doka G (2013) Updates to life cycle inventories of municipal waste incineration

ECDC (2020) Using face masks in the community, European Centre for Disease Prevention and Control

Ecoinvent (2021) Ecoinvent Database v3.7.1

EDANA (2021) European Nonwovens Production and Deliveries Report. https://www.edana.org/nw-related-industry/nonwovensmarkets

Ellen MacArthur Foundation (2017) A new textiles economy: redesigning fashion's future. http://www.ellenmacarthurfoundation. org/publications 
Fadare OO, Okoffo ED (2020) Covid-19 face masks: a potential source of microplastic fibers in the environment. Sci Total Environ 737:140279-140279. https://doi.org/10.1016/j.scitotenv.2020. 140279

Faist Emmenegger M, Bajaj S, Datta A, Nigam M, Mosharraf Hossain M, Noor Hossain M (2018) Life cycle inventories of textile products - India and Bangladesh

Greenhalgh T, Chan XH, Durand-Moreau Q, Straube S, Devane D, Toomey E, Khunti K, Adisesh A (2020) What is the efficacy of standard face masks compared to respirator masks in preventing COVID-type respiratory illnesses in primary care staff?

Guinée JB, Gorrée M, Heijungs R, Huppes G, Kleijn R, Koning A (2002) Life cycle assessment: An operational guide to the ISO standards: part 2a http://www.leidenuniv.nl/cml/ssp/projects/lca2/ lca2.html

Howard J, Huang A, Li Z, Tufekci Z, Zdimal V, van der Westhuizen H-M, von Delft A, Price A, Fridman L, Tang L-H (2020) Face masks against COVID-19: An evidence review

ISO (2006a) Life cycle assessment - principles and framework

ISO (2006b) Life cycle assessment - requirements and guidelines

Itten R, Frischknecht R, Stucki M (2014) Life Cycle Inventories of Electricity Mixes and Grid. Version 1:3

Klemeš J, Fan Y, Jiang P (2020) The energy and environmental footprints of COVID-19 fighting measures - PPE, disinfection, supply chains. Energy 211:118701. https://doi.org/10.1016/j.energy. 2020.118701

Lee AWL, Neo ERK, Khoo Z-Y, Yeo Z, Tan YS, Chng S, Yan W, Lok BK, Low JSC (2021) Life cycle assessment of single-use surgical and embedded filtration layer (EFL) reusable face mask. Resour Conserv Recycl 170:105580-105580. https://doi.org/10.1016/j. resconrec.2021.105580

Leung NHL, Chu DKW, Shiu EYC, Chan K-H, McDevitt JJ, Hau BJP, Yen H-L, Li Y, Ip DKM, Peiris JSM, Seto W-H, Leung GM, Milton DK, Cowling BJ (2020) Respiratory virus shedding in exhaled breath and efficacy of face masks. Nat Med 26(5):676680. https://doi.org/10.1038/s41591-020-0843-2

Liu X, Zhang S (2020) COVID-19: Face masks and human-to-human transmission. Influenza Other Respir Viruses 14(4):472-473. https://doi.org/10.1111/irv.12740

Oberg T, Brosseau LM (2008) Surgical mask filter and fit performance. Am J Infect Control 36(4):276-282. https://doi.org/10.1016/j.ajic. 2007.07.008

OceansAsia (2020) OceansAsia report for immediate release: December 7, 2020. Retrieved 2020 from https://oceansasia.org/covid19-facemasks/
Schmutz M, Hischier R, Batt T, Wick P, Nowack B, Wäger P, Som C (2020) Cotton and surgical masks - what ecological factors are relevant for their sustainability? , 12(24):10245. https://www. mdpi.com/2071-1050/12/24/10245

Selvaranjan K, Navaratnam S, Rajeev P, Ravintherakumaran N (2021) Environmental challenges induced by extensive use of face masks during COVID-19: a review and potential solutions. Environ Chall 3:100039. https://doi.org/10.1016/j.envc.2021.100039

Sphera (2021) GaBi LCA Software and Database v.10.5

TUIK (2020) Foreign Trade Statistics 2020. Turkish Statistical Institute. https://data.tuik.gov.tr/Bulten/Index?p=Dis-Ticaret-Istatistik leri-Ocak-2021-37413

van Straten B, Ligtelijn S, Droog L, Putman E, Dankelman J, Weiland NHS, Horeman T (2021) A life cycle assessment of reprocessing face masks during the Covid-19 pandemic. Sci Rep 11(1):17680. https://doi.org/10.1038/s41598-021-97188-5

WHO (2020a) Advice on the use of masks in the context of COVID19: Interim guidance. https://apps.who.int/iris/bitstream/handle/ 10665/331693/WHO-2019-nCov-IPC_Masks-2020.3-eng.pdf? sequence $=1 \&$ isAllowed $=\mathrm{y}$

WHO (2020b) Coronavirus disease (COVID-19) advice for the public: When and how to use masks. https://www.afro.who.int/news/coron avirus-disease-covid-19-advice-public-when-and-how-use-masks

WHO (2020c) Novel coronavirus (2019-nCoV) situation report - 1 World Health Organization. https://www.who.int/docs/defaultsource/coronaviruse/situation-reports/20200121-sitrep-1-2019ncov.pdf

WHO (2020d) Shortage of personal protective equipment endangering health workers worldwide. https://www.who.int/news/item/ 03-03-2020-shortage-of-personal-protective-equipment-endan gering-health-workers-worldwide

WHO (2020e) Statement regarding cluster of pneumonia cases in Wuhan, China World Health Organization. https://www.who.int/ chinanews/detail/09-01-2020-who-statement-regarding-clusterof-pneumonia-cases-in-wuhan-china

Zheng J (2020) SARS-CoV-2: an emerging coronavirus that causes a global threat. Int J Biol Sci 16(10):1678-1685. https://doi.org/ 10.7150/ijbs. 45053

Publisher's Note Springer Nature remains neutral with regard to jurisdictional claims in published maps and institutional affiliations. 